\title{
Psychological Contract and Employee Retention in Private Organizations
}

\author{
Sowemimo Olatunji Zacchaeus \\ Department of Business Administration, Olabisi Onabanjo University, Ago-Iwoye, Nigeria
}

\section{Email address:}

olatunjisowemimo@yahoo.com

\section{To cite this article:}

Sowemimo Olatunji Zacchaeus. Psychological Contract and Employee Retention in Private Organizations. International Journal of Management and Fuzzy Systems. Vol. 7, No. 3, 2021, pp. 41-46. doi: 10.11648/j.ijmfs.20210703.11

Received: May 10, 2021; Accepted: May 27, 2021; Published: August 18, 2021

\begin{abstract}
The inability to keep the essential human resource of an organization has become detrimental to many of such organizations and the growing complexity in the business environment has forced management to stress on employee retention by adapting various means. This research is aimed at examining the association between contracts which are psychological and employee retention in private organizations. It also examines the extent at which psychological contract dimensions are related with the retention of employees. Cross-sectional and quantitative approach was adopted for the study where a sample of 90 members of Victory Life Bible Church who are employees of different private organizations in Abeokuta was chosen through convenience sampling technique and structured questionnaire was used for data collection. The primary data collected for the study was analyzed using Pearson Correlation with the help of Statistical Package of Social Sciences (SPSS). From the findings of the research, it was confirmed that psychological contract is positively related with employee retention; it also showed that psychological contract dimensions are highly associated with retention of employees. It is recommended by the study that psychological contract be considered as part of the organizations' strategies to maintain and retain resourceful employees who would coordinate the other resources of the organization towards the attainment of corporate goals and organizational effectiveness.
\end{abstract}

Keywords: Psychological Contract, Employee Retention, Organizational Citizenship Behavior

\section{Introduction}

The increased attention placed on using human resource towards the effective and efficient creation of goods and services over the years has put the people in the workplace in an important position regarding competitive advantage for enterprises [7]. Nonetheless, continuous movement of people out of organizations has become a major challenge for many enterprises. This is because increased turnover rate will not only lead to a rise in the overall cost of replacing the migrating workforce, but also negatively affect the morale of the organization as well as weakening the intellectual asset base of the firm; this is obviously not good for the healthy development of enterprises. Researchers and professionals in the field of human resources (HR) agree that the work relationship is no longer what it used to be as different essential improvements have come into the relationship and this leads to different implications for the recruitment and retention of valuable employees [10].

Psychological Contract (PC) provides a structure with which employee attitudes and main concerns can be monitored, using the dimensions that can be of great effect in ensuring that employees pledge their nearest future to the organization. This is important as any organization that seeks to successfully actualize its goals have to ensure that its human resource and always in position where they give their best to the organization. And for this to happen, organizations need to know what the expectation of their workforce on the organization is. The identification and effective fulfilment of this expectation would help the management in executing the firm's side of the contract [6]. Psychological contract also extends to other responsibilities of the organization which include job security, personal or career development, worklife balance and several rewards.

Over the years, the business environment has developed widely owing to the competition and globalization of the international markets. This has led to increased flexibility for organizational process and enhanced productivity. This development gave rise to different consequences for the organization in terms of recruiting and retaining their best 
workforce and has led to further complications as regards the expectations and responsibilities that the employees and employers have of one another [5]. Therefore, this study examines the relationship between the psychological contract and retention of employees considering the different dimensions of psychological contract.

\subsection{Aims and Objectives}

The aim of this study is to examine the relationship between psychological contract and employee retention in private organizations and this is further broken down into the following objectives:

i. To examine the relationship between good work environment and employee retention.

ii. To identify the relationship between bonuses/allowances and employee retention.

iii. To investigate the relationship between personal/career development and employee retention.

iv. To explore the relationship between work-life balance and employee retention.

v. To examine the relationship between psychological contract and employee retention.

\subsection{Research Questions}

The research questions set out for the study are as follows:

1. What is the relationship between good work environment and employee retention?

2. Do bonuses/allowances have any relationship with employee retention?

3. Does personal/career development have any relationship with employee retention?

4. Is there any relationship between work-life balance and employee retention?

5. What is the relationship between psychological contract and employee retention?

\subsection{Research Hypotheses}

Based on the research questions and objectives, the following hypotheses were considered:

$\mathrm{H}_{\mathrm{O} 1}$ : Good work environment does not have significant relationship with employee retention.

$\mathrm{H}_{\mathrm{O} 2}$ : Bonuses/allowances have no significant relationship with employee retention.

$\mathrm{H}_{\mathrm{O} 3}$ : Personal/career development has no significant relationship with employee retention.

$\mathrm{H}_{\mathrm{O} 4}$ : There is no significant relationship between work-life balance and employee retention.

$\mathrm{H}_{\mathrm{O} 5}$ : There is no significant relationship between psychological contract and employee retention.

\section{Literature Review}

\subsection{Conceptual Review}

\subsubsection{Psychological Contract}

In any organization, there are formal and informal relationships. The formal relationship and expectation are well stated and understood. However, the informal expectation within the employment relationship could be ambiguous and parties may have to discover it so as to work on it for a good employment relationship. Literatures in the field of strategic human resource management expressed that the concept of psychological contract speaks of Argyris' study conducted in the year 1960. Psychological Contract as a concept was introduced in the 1960s when Argyris posited the concept to mean unspoken agreement in an employment relationship [12]. The psychological contract was thereafter explained as a means of exchange in a social relationship that exists in a work environment and employment agreement [18]. Schein (1978) also defines the concept as an informal expectation of employees and their employers going beyond the agreement which is formal just as Newell \& Dopson (1996) describe the concept as the services and loyalty that people in the workplace are prepared to offer their employer with expectation of something in return from the organization. The basic idea is that one of the best approaches for employer to get the best out of their workers is to meet their expectations which represent an informal employee culture. This is because when psychological contract is respected by employers, it advances employee empowerment, thereby plummeting employee turnover and enhance overall efficiency [11]. Also, some psychological contract could be in written form which relates to the transactional type. In summary, Psychological Contract implies employees' personal or subjective understanding, interpretation and assessments of their deal with their employers [16].

\subsubsection{Types of Psychological Contract}

\section{(i) Transactional Psychological Contract}

This type of psychological contract implies a definite exchange between an employee and employer which can be monetize over a specific period of time [19]. It relates to the written expectations of employees. Transactional contract signifies that the employee is aware of the expectation of the employee is only obliged to do same as stated in exchange for monetary values. In this type of contract, the organization is indebted to offer adequate compensation to employee as an exchange for services rendered. However, the employer is not under any compulsions to further provide additional training and development to the employee just as the later also is not under any obligation to remain with the organization in the future, and as such, the employer does not security of the employment for the future beyond the limited period of time agreed at the inception of the contract [5]. Rousseau (2004) argued that psychological contracts which are transactional are narrow duties and usually in short term employment. He added that employees with transactional contract are likely to stick with the exact initial conditions of employment and to pursue opportunities elsewhere in an event that the conditions change or when employers fail to fulfil their agreement.

(ii) Relational Psychological Contract

Curwen (2013) explained that relational type of 
psychological contract is relationship contract that is built on trust, unspoken emotional attachment, and that it embraces long-term employment. In relational contract, the employees are interested in working with the employer in the long term and carry out their duties as specified, demonstrate loyalty to support the aims and objectives of the organization as he expects the organization to carry out its part of the agreement through the well-being of the employees on and off the job [5].

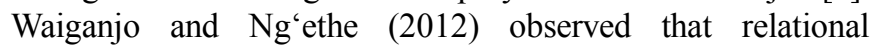
psychological contract is likely to come with upset for employees particularly when such is violated, but because of the employee' commitment in the contract, they often opt for options that will ensure their relationship with the organization is not broken noting that failure to address any violation of the agreement typically would lead to turnover or if the employee decides to stay put, the contribution of such employee to the organization will be reduced and this may further lead to the wearing away of the employment relationship.

\section{(iii) Transitional Psychological Contract}

This type of psychological contract is more of a makeshift arrangement where the changes in organizational context and socio-economic are reflected and transitions made are in contradiction with a previously established arrangement or psychological contract [9]. It is basically a collapse in contracts, showing the lack of commitments in respect of future employment as well as no specific performance demands or conditional incentives. This state is usually experienced during organization's process of merging with another or acquiring another and uncertainties in work life.

\section{(iv) Balanced/Hybrid Psychological Contract}

This contract represents a flexible employment with well spelt out performance terms which are subject to change from time to time. This type of psychological contract is dynamic and based on business success of the organization and employees' personal/career development based on performance and skills [9]. It is a win-win approach where both the organization and employee contribute to each other's growth and development. Compensation to employees is based upon performance standards while contributions to the organization's business success are a function of how effective the organization meets the employees' informal expectation.

\subsubsection{Organisational Citizenship Behaviour (OCB)}

The Organisational Citizenship Behaviour (OCB) refers to the willingness of employees to work for their employers beyond the job descriptions given so as to ensure the attainment of organizational goals [13]. Van Dyne, Graham and Dienesch (1994) refer to the concept as meaning performing extra-role on the job outside the specified and it is seen as behaviour based on intent to benefit others (prosocial) by O'Reilly and Chatman, 1986 while OCB is viewed by George and Jones 1997 as an impulsive act of seeing one as a stakeholder in the organization for certain reasons and willing to do extra for the organization. The concept is also described as contextual employee performance by [2] Podsakoff, MacKenzie, Paine and Bachrach (2000) established that there are nine dimensions of OCB which are tolerance, cooperative attitude, good self-enhancement, loyalty, internalisation of the organisation aspects, helping at work, tolerance, the effort to developing positive organisational responsibility.

\subsubsection{Employee Retention}

The concept of employee retention is described as an approach adopted in managing the employees so as to ensure they are kept for a longer engagement period than the other competitors. This is achieved by implementing different retention management strategies. It is a deliberate move made by firms to nurture an environment which helps employees to pledge their services for a long-term period within the organization [3]. Sandhya and Kumar (2011) perceives employee retention as a win-win situation to both the employer and worker, and this encourages staff to pledge their nearest future to the organization for a maximum period until an agreement reached is seen completed.

\subsubsection{Factors Influencing Employee Retention}

There are many reasons why employees leave an organisation, some of which include lack of career development, inadequate recognition, lack of team work and rigid work schedules [14]. When employees also perceived that there are future opportunities and that their expectations are likely going to be met, this also contributes to employee retention [8]. Horwitz, Heng and Quazi, 2003 also posits that rewards in financial, career development, content and work life balance also influence the organization's ability to retain its employees.

\subsection{Empirical Review}

Researchers in human resources management field through various studies have been able to establish that psychological contract fulfilment is key in employee retention. Robinson (1996) explained that a feeling of psychological contract breach has a negative effect on the employee's desire to continuously work with the organisation. He further explained that this explains why some local firms in Zimbabwe are having a tough time retaining their most skilled and capable talents. Guest and Conway (2002) also confirmed that a psychological contract fulfilment brings about higher commitment, happiness and enthusiasm of the employee to stay with the organisation. Nelesh and Sanjana (2014) established that an unfulfilled psychological contract leads to a decline in willingness to contribute and intentions to stay in an organisation. When an employee perceives that his implicit interpretation of a contract is violated, this brings down the moral to contribute to the organisation and his or her desire to stay for the nearest future [15].

\subsection{Theoretical Review}

This study is guided by the Social Exchange Theory.

The social exchange theory helps to understand how the breakdown of a relationship as psychological contract may bring about ill feelings. Blau (1964) cited by Vos, Meganck and Buyens (2006) explain the social exchange theory as the 
willingness of individuals to act in a particular manner while expecting something in returns for such action. Cropanzano and Mitchel (2005) suggest that the relationship consists of people who are influenced to behave in a manner as a result of their belief that both will reciprocate the doings of one another over time. And as such, if any of the parties fails to return the efforts of the other, a feeling of dissatisfaction arises in the relationship between the parties involved. Therefore, in any work relationship, if workers perceive that their foremen fail to give a commensurate return to their contributions towards the organization, the employees are likely to react through unfavourable emotions and negative attitudes. Furthermore, these employees could come up with a model through which the observed one-sidedness would be addressed either by a reduction of their organizational commitment or downward exhibition of other important behaviours and attitudes [17].

\section{Methodology}

This study was based on descriptive research using survey method which makes it possible to collect information about target audience without having to deal with the entire population. The population for this study were members of Victory Life Bible Church, Abeokuta who are employees of private organizations. Therefore, the target population was 438 members of the church who currently work with private firms across the city. The convenience sampling technique was explored and a total of ninety (90) respondents were used for this study drawn from the population. This technique and sample size was chosen due to the availability of the target population and the researcher's time limitation since this study was to be undertaken within a specific time frame. Primary data was collect from respondents using a wellstructured questionnaire and the Statistical Package for Social Science (SPSS) was used in analysing the gathered data after providing suitable codes for every question considered in the questionnaire. The correlation analysis being a statistical technique to analyse the relationships between variables was the major statistical tool used as it is measured by correlation coefficient (r) which shows the numerical measure of linear relationships between the two variables [4]. Pilot Study was conducted to test the clarity and appropriateness of the questionnaires where 5 bank tellers of financial institutions and 5 marketers of telecommunication companies in Abeokuta were used for the pilot study. From the pilot study, it was established that the proposed questionnaire instrument is understandable and can be answered within 7-9 minutes. The Cronbach's alpha $(\alpha)$ value was found to be 0.903 indicating an acceptable level of research instrument reliability.

\section{Data Analysis and Interpretation}

\section{Test of Hypotheses}

$\mathrm{H}_{\mathrm{O} 1}$ : Good work environment does not have significant relationship with employee retention.

$\mathrm{H}_{\mathrm{O} 2}$ : Bonuses/allowances have no significant relationship with employee retention.

$\mathrm{H}_{\mathrm{O} 3}$ : Personal/career development has no significant relationship with employee retention.

$\mathrm{H}_{\mathrm{O} 4}$ : There is no significant relationship between work-life balance and employee retention.

Table 1. Correlation between Dimensions of Psychological Contract and Employee Retention.

\begin{tabular}{llllll}
\hline & & $\begin{array}{l}\text { Employee } \\
\text { Retention }\end{array}$ & $\begin{array}{l}\text { Good Work } \\
\text { Environment }\end{array}$ & $\begin{array}{l}\text { Bonuses \& } \\
\text { Allowances }\end{array}$ & $\begin{array}{l}\text { Personal/ } \\
\text { Career Development }\end{array}$ \\
\hline Employee & Pearson Correlation & 1 & $.538^{* *}$ & $.355^{* *}$ & $.687 * *$ \\
Retention & Sig. (2- tailed) & & 0.000 & 0.001 & $.605 * *$ \\
\hline
\end{tabular}

**. Correlation is significant at the 0.01 level (2-tailed).

Source: Survey data, 2019.

Table 1 shows that each dimension of psychological contract is positively correlated with employee retention. However, the dimensions exhibits varying degrees of correlation as good work environment $0.538 \quad(53.8 \%)$, personal/career development $0.687(68.7 \%)$, and work-life balance 0.605 $(60.5 \%)$ show high positive correlation while bonus and allowance $0.355(35.5 \%)$ shows weak positive correlation. Thus, this correlation analysis shows that psychological contract dimensions are positively associated with employee retention; hence, $\mathrm{H}_{\mathrm{O} 1}, \mathrm{H}_{\mathrm{O} 2}, \mathrm{H}_{\mathrm{O} 3}$ and $\mathrm{H}_{\mathrm{O} 4}$ were rejected.

$\mathrm{H}_{\mathrm{O} 5}$ : There is no significant relationship between psychological contract and employee retention.

Table 2. Correlation between Psychological Contract and Employee Retention.

\begin{tabular}{llll}
\hline & & Psychological Contract & Employee Retention \\
\hline \multirow{3}{*}{ Psychological Contract } & Pearson Correlation & 1 & $.624^{* *}$ \\
& Sig. (2-tailed) & & .000 \\
& $\mathrm{~N}$ & 90 & 90 \\
\multirow{2}{*}{ Employee Retention } & Pearson Correlation & $.624^{* *}$ & 1 \\
& Sig. (2-tailed) & .000 & 90 \\
\hline
\end{tabular}

**. Correlation is significant at the 0.01 level ( 2 tailed).

Source: Survey Data, 2019. 
Table 2 shows that psychological contract is positively correlated with employee retention at $0.624(62.4 \%)$. This correlation analysis shows that psychological contract is positively and highly associated with employee retention; hence, the $\mathrm{H}_{\mathrm{O} 5}$ hypothesis was rejected.

\section{Discussion of Findings}

This research was carried out to examine the relationship between psychological contract and employee retention in private organizations in Abeokuta, Ogun State. The study also investigated the association between psychological contract dimensions and employee retention. The study found that psychological contract is positively and highly correlated with employee retention at $62.5 \%$ which implies that implies that having psychological contract ensures high level of employee retention within the organization. The study also found that the different measurements of psychological contract all have positive correlation with retention of employees and further indicated that personal/career development shows the highest association with $68.7 \%$ correlation while bonuses and allowances shows the weakest association with $35.5 \%$.

These findings are consistent with the findings of Weralupitiya and Yasodara (2016); he has claimed that psychological contract is found to be positively related with employee retention while also asserting that dimensions such as stimulating job, work atmosphere, autonomy, salary, intra organizational mobility and work-life balance are all dimensions of psychological contract and they show positive relationships with employee retention.

\section{Conclusion and Recommendation}

The increasing attention paid towards retention is justified because of several reasons ranging from keeping the best to reducing the cost of recruitment. The growing complexity in the organization has forced management to stress on retention of their employees by adapting various means. The concept of psychological contract has also emerged as one of the important tools of employee wellbeing and to keep them in the organization for as long as possible. The study concluded that majority of employees in private organizations in Abeokuta are satisfied with the current fulfilment state of their psychological contract with their employers. Majority felt their employers had honour the contract leading to employees willing to commit their long term future to the organizations. The study showed that most employees of the private organizations do not have the intention of leaving the firms as long as it keeps fulfilling their need of psychological contract. It can be concluded to mean that while psychological contract may not be the sole contributor to employee retention, it influences to a large extent the decision of employees to remain in the private organizations within Abeokuta in the nearest future. Therefore, it is recommended that psychological contract be considered as part of the organizations strategy to maintain and retain resourceful workforce who will assist in driving the organizational goals in this globalized economy towards organizational effectiveness.

\section{Limitations of the Study}

This research was limited by time majorly as it was conducted in a limited period of time, with limited resources and limited expenses. The data used was also collected from just 90 employees of private organizations in Abeokuta who are members of a church, and so it may not represent the overall position of the entire private organization employees in the area.

\section{Suggestion for Further Studies}

There is need to replicate this study in public institutions and a larger sample size is also recommended.

\section{References}

[1] Arthur, J. L. \& Kolson, M. F. (2017). Psychological Contract Fulfillment and its implication on Performance of Employees. Journal of Public Administration and Policy Research, 9 (2), 17-25. https://doi.org/10.5897/JPAPR2017.0402.

[2] Borman, W. C., \& Motowidlo, S. J. (1997). Task performance and contextual performance: The meaning for personnel selection research. Journal Human Performance, 10 (2), 99109. https://doi.org/10.1207/s15327043hup1002_3.

[3] Chaminade, B. (2007). A Retention Checklist: How do you rate? [Online]. Available at: http://www.hcamag.com/resources/hr-strategy/a-retentionchecklist-how-do-you- rate/112621.

[4] Creswell, J. W. (2002). Educational Research: Planning, Conducting, and Evaluating Quantitative and Qualitative Research. Upper Saddle River, NJ: Merrill Prentice Hall.

[5] Dipankar, S. (2013). Human Resource: Managing Psychological Contract. Retrieved from http://www.llPM.edu). Retrieved May 12, 2015.

[6] Festing, M. \& L. Schafer. (2014). Generational Challenges to Talent Management: a Framework for Talent Retention Based on the Psychological Contract Perspective.' Journal of World Business, 49: 262-271.

[7] Halawi, L., Aronson, J. \& McCarthy, R. (2005). ResourceBased View of Knowledge. Journal of Human Resources Management, 24 (3), 125-141.

[8] Hannay, M. (2002). Low Cost Strategies for Employee Retention. SAGE: London.

[9] Harold, A. P. (n. d.). Psychological Contract and Employment Relationship. Retrieved from: researchgate.net/publication/228196969_Psychological_Contr act_and_Employ ment_Relationship/download.

[10] Horwitz, F., Heng, C., \& Quazi, H. (2003). Finders, Keepers? Attracting, Motivatin and Retaining knowledge workers. Human Resource Management Journal, 13 (4), 23-44. 
[11] Ndindeng, A. (2020). The Psychological Contract. Week 2, 1-3. Retrieved from https://www.researchgate.net/publication/339777196 The Ps ychological_Contract\&ved=2ahUKEwiiv5mG_ubwĀhU0gf0 HHXqzCOgQFjAKegQIFxAC\&usg=AOvVaw0aSVQe75wUIZs2xPK4nhV.

[12] Nelesh, D. \& Sanjana, B. P. (2014). Re-establishing the Psychological Contract as a Precursor to Employee Retention. Problems and Perspectives in Management, 12 (4), 78-90.

[13] Organ, D. W. (1997). Organizational citizenship behavior: It's construct clean-up time. Human Performance, 10 (2), 85-97. https://doi.org/10.1207/s15327043hup1002_2.

[14] Raja, U., Johns, G., \& Ntalianis, F. (2004). The impact of personality on psychological Contracts. Academy of Management Journal, 47, 350-367.

[15] Robinson, S. L. (1996). Trust and Breach of the Psychological Contract. Administrative Science Quarterly, 41 (4), 574-599.
[16] Rousseau, D. M. (2001). The Idiosyncratic Deal: Flexibility Versus Fairness? Organizational Dynamics, 29 (4), 260-273.

[17] Taylor, M. S., and A. G. Tekleab. (2004). Taking Stock of Psychological Contract Research: Assessing Progress, Addressing Troublesome Issues, and Setting Research Priorities. Retrieved from: http://teaching.ust.hk/ mgto650r/clee/Day_3_reading_materia 1/stock.pdf.

[18] Turnely, W. H. \& Feldman, D. C. (2000). Re-examining the Effects of Psychological Contract Violations: Unmet Expectations and Job Dissatisfaction as Mediators. Journal of Organizational Behaviour, 21, 25-42.

[19] Waiganjo, E. W. and $\mathrm{Ng}^{6}$ ethe, J. M. (2012). Effects of Human Resource Management Practices on Psychological Contract in Organizations. International Journal of Business and Social Science, 3 (19), 117-122. 